Bull. Fac. Agric., Cairo Univ., 58 (2007):217-221

\title{
BIOLOGICAL CONTROL OF CUCUMBER DAMPING-OFF CAUSED BY Pythium aphanidermatum
}

(Received:22.1.2007)

\author{
By \\ N. S. Al-Ameiri \\ Department of Plant Protection and Integrated Pest Management, Faculty of Agriculture, \\ University of Mutah, Karak, Jordan.
}

\begin{abstract}
Seven treatments were applied to the soil in a greenhouse to control cucumber damping - off Trichoderma harzianum was used in the four of them. T.harzianum preparations applied to soils infested with Pythium aphanidermatum (natural and artificial) decreased disease incidence, severity and increased shoot dry weight. Mycelium and mycelial preparation appear to be more effective than conidia and conidial preparation. The mycelial preparation was the best in controlling the disease.
\end{abstract}

Key words: cucumber, damping-off, Pythium aphanidermatum, Trichoderma harzianum.

\section{INTRODUCTION}

Biological control of plant pathogens is becoming an important component of plant disease management practices (Cook and Baker, 1983). Different isolates of Trichoderma spp. appeared to be effective in controlling an array of soil-borne pathogenic fungi (Hadar et al., 1979; Elad et al., 1980; Lewis and Papavizas, 1985; Mohamed and Abu-Raya, 1993; Adm, 2000; and Al-Ameiri, 2001).

Trichoderma spp. have also been used to protect seeds of cucumber, tomato, okra and pea against Pythium damping-off in both green house and field trials (Hadar et al., 1984; Harmen and Tyler, 1988; Paulitz et al., 1990; Adm, 2000; and Al-Ameiri, 2001). This isolate reduced Pythium damping - off and colonization of cucumber root tips induced by Pythium ultimum (Ahmad and Baker, 1988; and Paulitz et al., 1990). A wide variety of Pythium spp. has been described from a greenhouse production systems (Van der PleatsNitterink, 1981 ). The genus of Pythium includes a number of readily recognized species with wide distribution and host range (McCarter and Littrell, 1970). Pythium aphanidermatam is one of the most serious pathogens of cucumber, tomato, and sugarbeets at the seedling stages causing both pre-and post - emergence damping - off (McCarter and Littrell, 1970; Patel and Patel, 1975; Adm, 2000; and Al-Ameiri, 2001).

P.aphanidermatum prefers temperatures between 27 and $34{ }^{\circ} \mathrm{C}$, wet conditions and approximately $6.2 \mathrm{pH}$ (Lumsden et al., 1976).
Furthermore, the numbers of propagules are increased through August and September while decreased in March and April (Leach, 1947; and Dewan, 1994).

The objectives of this study were to assess the efficacy of biocontrol agent in controlling Pythium damping - off of cucumber in green house and to compare the effect of young mycelial preparation and conidial preparation of biocontrol agent in controlling Pythium damping - off of cucumber.

\section{MATERIALS AND METHODS}

Soil used in the experiment was taken from plastic house where the pathogens isolated. The soil had the following characteristics: a $\mathrm{pH}$ of 7.2, total $\mathrm{N}$ of $0.22 \%$, P of $160 \mathrm{ppm}, \mathrm{K}$ of $350 \mathrm{ppm}$ and $2.1 \%$ organic matter. The soil was divided into two parts, the first was without steaming (raw soil) natural infested (25-35 CFU / g) Pythium aphanidermatum and the other was steamed by autoclaving three times at $80{ }^{\circ} \mathrm{C}$ for one hour. The investigation was performed using plastic pots, 15 $\mathrm{cm}$ in diameter round, $500 \mathrm{~g}$ soil/pot.

Inoculum's isolate of Pythium aphanidermatum was isolated from diseased cucumber plants , grown in plastic house at Rabba Agriculture Station dead infected seedling at the stem base and rotting roots in post-emergence damping - off of cucumber seedlings rinsed in tap water for an hour, disinfected by $0.50 \%$ sodium hypochlorite, then rinsed in sterile water, dried on filter paper and then plating on PDA, identified according to Waterhouse (1968), maintained on potato 
dextrose agar (PDA), the inocula were incubated under specific conditions at $22^{\circ} \mathrm{C}, 10 \times 3 \times 2 \mathrm{~cm}$ glass tubes covered with aluminum foil.

Trichoderma harzianum was isolated from the same soil, by dilution method plated and identified according to Rifai (1969) mutagenized by benomyl tolerant as described by Ahmad and Baker (1987) and grown on (PDA) containing 10 $\mu \mathrm{g}$ a.i. benomyl $/ \mathrm{ml}$. Factorial arrangements $(7 \times 2)$ contained three replicates per treatment on the greenhouse bench in a completely randomized design. The seven treatments were; control (1) Pythium aphanidermatum alone, control (2) no pathogen and no biocontrol agent (3) autoclaved wheat bran $5 \mathrm{~g} / \mathrm{kg}$ of soil and Pythium aphanidermatum (4) conidia suspension (Trichoderma harzianum grown on (PDA) at $25^{\circ}$ $\mathrm{C}$ were harvested by scraping the surface of the colonies with a spatula and transferred to flash of water to give a spore concentration at $10^{7}-10^{8}$ / $\mathrm{ml}$ and $40 \mathrm{~m} V$ pot added (5) conidial preparation; $150 \mathrm{~g}$ of wheat bran and $150 \mathrm{ml}$ of water were autoclaved at $121^{\circ} \mathrm{C}$ for $1 \mathrm{~h}$ twice, cooled then 40 $\mathrm{ml}$ of the above conidia suspension were added directly to wheat bran and $5 \mathrm{~g} / \mathrm{kg}$ of the soil were added as conidial preparation before incubation (6) mycelium; potato dextrose (PD) medium was autoclaved then cooled, seeded with $0.5 \mathrm{~cm}$ of Trichoderma harzianum disc and incubated for three days. The mycelium was filtered by filter papers type (Whatman) repeated three times, and washed to be free from nutrient before addition to the soil (5g/ $\mathrm{kg}$ of the soil) and (7) mycelial preparation; a modification of the wheat bran culture (used as a carrier and food substance for Trichoderma harzianum to increase effectiveness) for the biocontrol was used (Hadar et al., 1979) by autoclaving wheat bran then inoculated by conidia suspension as the same concentration above, incubated for five days and then dried (at room temperature) for three days $5 \mathrm{~g} / \mathrm{kg}$ of soil. Half of Pythium aphanidermatum dishes, $9 \mathrm{~cm}$ diameter, of two day old were added to pots in the sixth treatment (Saydam, et al., 1973). Two days later, the soils were inoculated with biocontrol agents. After one day, ten cucumber (Cucumis sativus) variety (beit alpha) seeds were planted in pots and watered daily. Seven days later, the number of seeds, which did not germinate, was calculated as a pre - emergence damping - off. The damping off. Post - emergence damping - off were after two weeks (number of dead seeds (pre-emer.) or dead and infected seedling (post-emer.) / total number per pot $\mathrm{x} 100 \%$ ), and the seedlings were thinned to one / pot. Damping - off seedlings were planted on (PDA) routinely to identify the pathogen. Disease severity, incidence and shoot dry weights were recorded. Disease severity was recorded on a scale of $(0-3)$ where 0 , healthy seedling, 1 diseased seedling (infected seedling and did not die during experiment time lesion appeared brown in color at lower stem near the soil line), 2 dead post - emergence and 3 dead preemergence.

\section{RESULTS}

Addition of Trichoderma harzianum to the soil with all treatments significantly reduced preand post - emergence damping-off of cucumber compared to Pythium aphanidermatum alone (Table 1) . In the steamed soil, pre- emergence damping - off with the pathogen reached $70 \%$ while in raw soil it was considerably less. Mycelium and mycelial preparation reduced disease incidence at pre -and post -emergence than $100 \%$ higher than conidia and conidial preparation. In the raw soil, pre-emergence disease pressures were lower than in the steamed soil. The combination of wheat bran and pathogen significantly increased disease incidence in preemergence damping - off at steamed soil if compared with raw soil $(53.33 \%, 30 \%)$ while no significant differences were observed at post emergence between the two soils $(33.33 \%$, $26.076 \%$; respectively) (Table 1). Mycelial preparation significantly reduced pre- damping off incidence than conidia and conidial preparation, with most of the reduction occurred in post-emergence (Table 1).

Disease severity significantly increased with Pythium aphanidermatum only or with wheat bran added in artificial infested and raw soils more than Trichoderma harzianum treatments except conidia treatment in raw soil (Table 2). There was no significant difference between Trichoderma harzianum added in raw and steamed soil but the severity increased at raw soil except conidia treatment. In the raw soil, severity becomes less significant at pathogen only or with wheat bran than steamed soil. Mycelial preparation was significant by reduced infection more than conidia and conidial preparation in decreasing disease severity while no significant difference with mycelium treatment was detected (Table 2).

Trichoderma harzianum increased shoots dry weight at all types of application. T. harzianum added to raw and steamed soil significantly increased dry weight than treatment of Pythium 
Table (1): Effect of Trichoderma harzianum preparation on pythium pre and post- emergence damping - off percentage of cucumber planted in soil infested with Pythium aphanidermatum.

\begin{tabular}{|l|c|c|c|c|}
\hline \multirow{2}{*}{ Treatments } & \multicolumn{2}{|c|}{ Steamed soil (Artificially infested) } & \multicolumn{2}{l|}{ Raw soil (Naturally infested)* } \\
\cline { 2 - 5 } & $\begin{array}{c}\text { Pre-emergence } \\
\text { damping-off }\end{array}$ & $\begin{array}{c}\text { Post-emergence } \\
\text { damping-off }\end{array}$ & $\begin{array}{c}\text { Pre-emergence } \\
\text { damping-off }\end{array}$ & $\begin{array}{c}\text { Post-emergence } \\
\text { damping-off }\end{array}$ \\
\hline Pythium aphanidermatum & $70.00 * *$ a & 16.67 ghi & 40.00 c & 33.33 cde \\
\hline Control & $\mathbf{0 . 0 0}$ k & 0.00 k & 16.67 cd & 26.67 defg \\
\hline Wheat Bran & 53.33 b & 33.33 cde & 30.00 cdef & 26067 defg \\
\hline Conidia & 33.33 cde & 23.33 igk & 26.67 ghi & 16.67 ghi \\
\hline Conidial Preparation & 20.00 fgh & 6.667 igk & 20.00 fgh & 13.33 hij \\
\hline Mycelium & 16.67 ghi & 6.667 igk & 13.33 hij & 6.667 ijk \\
\hline Mycelial Preparation & 6.667 ijk & 3.333 jk & 13.33 hij & 6.667 ijk \\
\hline
\end{tabular}

* Naturally - infested with Pythium aphanidermatum (25-35 CFU/g)

** Each number is the mean of three replicates, numbers in the table followed by the same letter do not significantly differ from each other according to Duncan s multiple range test, $\mathrm{p}=0.05$.

Table (2): Effect of Trichoderma harzianum preparation on disease severity of cucumber planted in soil infested with Pythium aphanidermatum.

\begin{tabular}{|c|c|c|}
\hline Treatments & $\begin{array}{c}\text { Steamed Soil } \\
\text { (Artificially Infested) }\end{array}$ & Raw Soil (Naturally Infested)* \\
\hline Pythium aphanidermatum & $0.8557 * *$ a & 0.5443 \\
\hline Control & 0.000 & 0.2337 \\
\hline Wheat Bran & $\mathbf{0 . 8 3 3 7}$ & 0.6223 \\
\hline Conidia & 0.555 & 0.4777 \\
\hline Conidial Preparation & 0.323 & 0.3777 \\
\hline Mycelium & 0.2147 def & 0.289 \\
\hline Mycelial Preparation & 0.0890 fg & 0.1557 efg \\
\hline
\end{tabular}

Table (3): Effect of Trichoderma harzianum preparation on shoot dry weight of (g/ plant) Cucumber planted in soil infested with Pythium aphanidermatum .

\begin{tabular}{|l|l|ll|}
\hline Treatments & $\begin{array}{l}\text { Steamed Soil } \\
\text { (Artificial Infested) }\end{array}$ & $\begin{array}{l}\text { Raw Soil } \\
\text { (Natural Infested)* }\end{array}$ \\
\hline Pythium aphanidermatum & $\mathbf{0 . 2 8 0} * \mathbf{e}$ & $\mathbf{0 . 2 8 3} \quad$ e & \\
\hline Control & $\mathbf{0 . 4 0 3 3}$ cd & $\mathbf{0 . 3 7 3}$ & de \\
\hline Wheat Bran & $\mathbf{0 . 3 1 6 7}$ de & $\mathbf{0 . 3 0 6 7}$ & de \\
\hline Conidia & $\mathbf{0 . 3 9 6 7}$ cd & $\mathbf{0 . 4 0 6 7}$ & cd \\
\hline Conidial Preparation & $\mathbf{0 . 4 9 0} \quad$ bc & $\mathbf{0 . 5 0 6 7}$ & b \\
\hline Mycelium & $\mathbf{0 . 5 4 0} \quad$ b & $\mathbf{0 . 4 5 4}$ & b \\
\hline Mycelial Preparation & $\mathbf{0 . 6 7 0 7}$ a & $\mathbf{0 . 6 7 3}$ & a \\
\hline
\end{tabular}

* Naturally - infested with Pythium aphanidermatum (25-35 CFU/g)

** Each number is the mean of three replicates, numbers in the table followed by the same letter do not significantly differ from each other according to Duncan s multiple range test, $\mathrm{p}=0.05$.

aphanidermatum alone (Table 3).When the soils were amended with wheat bran, T. harzianum enhanced shoot biomass in both steamed and raw soils. T. harzianum application significant increased dry weight than treatment of Pythium aphanidermatum alone or with wheat bran except conidia treatment. Under the same treatment of Trichoderma harzianum, no significant differences were found between the two soils, and there were no significant differences between the control and wheat bran.

\section{DISCUSSION}

The results show that Trichoderma harzianum applied to the soil (steamed and raw) infested with Pythium aphanidermatum decreased disease incidence, severity and increase shoot dry weight (Tables 1, 2 and 3). These results are in agreement 
with those of (Hadar et al., 1979; Harmen and Taylor, 1988; Paulitz et al., 1990; Adm, 2000 and Al-Ameiri, 2001). Trichoderma spp. applied to the soil as mycelium and mycelial preparation decreased disease incidence and severity more than conidia and conidial preparation. This is attributed to that they are containing young active growing hyphae and abundant of chlamydospores, the hyphae already occupying the food base do not appear to be subjected to fungistases and that direct contact between mycelium and food base enable the antagonistic to grow through the soil (Lewis and Papavizas, 1983,1984 and 1985 ; Papavizas et al., 1984; and Al-Ameiri, 2001). Conidia of Trichoderma spp were used in disease control because they are abundantly produced on agar media and easy to handle. The results indicated that the conidia added to the soil from fresh culture with or without wheat bran were ineffective in decreasing the disease. They may need time to germinate to produce hyphae that are able to parasite and destroy the pathogen and leach by irrigation through the soil pores compared to mycelium. These results are in agreement with the results of Lewis and Papavizas, (1984) and Al-Ameiri, (2001). Suppression of the disease in raw soil occurred in absence of Trichoderma harzianum may be due to germination lyses of a known bacteria or fungal antagonist (Tsao and Oster, 1981; and Paulitz et al., 1990).

These results showed that the increase in disease incidence and severity occurred with the application of wheat bran to infested soil. This means that the pathogen utilized the food base (wheat bran) and increased its population because of the ability of Pythium spp.to live as saprophyte fungi and increase infections of hosts (Holmes et al., 1998; and Al-Amieri,2001).

The use of a bioagent also resulted in an increase of shoot dry weight in steamed and raw soils with or without wheat bran, this means that the bioagent is able to increase plant height and weight through protection from infection with the pathogens (Paulitz et al., 1990; Mohamed and Abo-Raya, 1993; and Adm, 2000).

\section{Acknowledgment}

I would like to thank Dr. K.Al-Absi for helping in statistical analysis.

\section{REFERENCES}

Adm K.A. (2000). Integrated Control of Seed, Root Rot and Damping-off of Tomato. Ph.D.Thesis, University of Mosul, Mosul, Iraq.
Ahmad J. S., and Baker R.(1987). Rhizosphere competence of Trichoderma harzianum. Phytopathology. 77:182-189.

Ahmad J. S. and Baker R. (1988). Implication of rhizosphere competence of Trichoderma harzianum.Can. J. Microbial. 34: 229-234.

Al-Ameiri N. S. (2001). Various Methods for Controlling Damping - off of Tomato Seedling in Nursery. Ph. D, Thesis, University of Mosul . Mosul., Iraq.

Cook R. J. and Baker K. F. (1983). The Nature and Practice of Biological Control of Plant Pathogens. American Phytopatholgical Society St. Paul., Mu.539pp.

Dewan M. M. (1994). The density number of pathogenic and non pathogenic fungi associated with tomato roots.Al-Basrah Agri.J. Science 7 (2) 91-100.

Elad Y. Chet. I. and Katan J. (1980). Trichoderma harzianum; A biocontrol agent effective against Sclerotium rolfsii and Rhizoctonia solani. Phytopathology. 70: 119-121.

Hadar Y., Chet I. and Henis Y. (1979). Biological control of Rhizoctonia solani with bran culture of Trichoderma harzianum. Phytopathology: 69:64-68.

Hadar Y., Harman G.E.and Taylor A.G. (1984). Evaluation of Trichoderma konini and Trichoderma harzianum from New York soils for biological control of seed rot caused by Pythium spp. Phytopathology 74: 106-110.

Harmen G. E. and Taylor A .G. (1988). Improved seedling performance by integration of biological control agents of favorable $\mathrm{pH}$ levels with solid matrix priming. Phytopathology. 78:520-525.

Holmes K.A., Nayagam S.D. and Gray G.D. (1998). Factors affecting the control of Pythium ultimum damping -off of sugar beet by Pythium oligandrum.. Plant Pathology. (47): 516- 522.

Leach L. D. (1947). Growth rates of host and pathogen as factors determining the severity of pre-emergence damping-off. J. Agri. Res.75:161-17.

Lewis J.A.and Papavizas G.C. (1983).Production of chlamydospres and conidia by Trichoderma spp.in liquid and solid growth media.Soil Biol. Biochem. 15: 351-357.

Lewis J. A. and Papavizas G. C. (1984). Chlamydospore formation by Trichoderma spp. in natural substrates.Can.J.Microbial.30: 1-7.

Lewis J.A .and Papavizas G.C. (1985). Effect of mycelial preparation of Trichoderma and 
Gliocladium on population of Rhizoctonia solani and induced of damping-off. Phytopathology. 75: 812-817.

Lumsden R.D., Ayer A., Adams P.B., Dow R.L., Lewis J.A., Papavizas G.C., and Kantzes J.G. (1976). Ecology and epidemiology of Pythium species in field soil. Phytopathology 66:12031209.

McCarter S. M. and Litterll R.H. (1970). Comparative pathogenicity of Pythium aphanidermatum and Pythium myriotyum to twelve plant species and intraspecific variation in virulence. Phytopathology 60:264-268.

Mohamed S. A. and Abo-Raya A. (1993). Biological control of tomato dampingoff.Menofiya. J.Agri.Res.18 (4):2131-2140.

Papavizas G.C., Dunn M.T., Lewis T. A. and Beagle-Ristaino J. (1984). Liquid fermentation technology for experimental production of biocontrol fungi. Phytopathology. 74:1171-1175.

Patel B. K. and Patel A.J. (1975). Fungi causing damping -off of tomato. Psychopathological notes.6:87-88.

Paulitz T.C., Ahmad J S. and Baker R. (1990).Integration of Pythium noun and
Trichoderma harzianum isolate T-95 for the biological control of pythium damping-off of cucumber. Plant and Soil.121:243-250.

Rifai M. A. (1969). A revision of the genus Trichoderma. Myco. Papers Imp. Mycol. Inst., 116, 1.

Saydam C.M., Copeu F. and Sezgin E. (1973). Studies on the inoculation techniques of cotton wilt caused by Verticillium dahlia Kleb. Infestation on the laboratory inoculation techniques.J.Turkish.Phytopathology.2:69-75.

Tsao P.H. and Oster J.J. (1981). Relation of ammonia and nitrous acid to suppression of Phytophthora in soils amended with nitrogenous organic substances. Phytopathology. 71:53-59.

Van der Pleats-Nitterink A.J. (1981).Monograph of The Genus Pythium.Studies in Mycology.No.21,W.Gams and R.P, W.Jacobs, Eds, Centraalbureau Voor Schimmelcultures.Baarn .Netherlands.

Weterhouse J .M. (1968). The genus Pythium priayshein diagnosis of description and figures from the original paper, Common Wealth Mycological Institute, Mycological papers,No.110.

\section{المقاومة الإحيائية لموت الخيار المفاجئ والمتسبب عن الفطر بيثيوم Pythium aphanidermatum

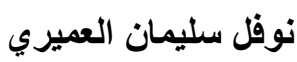$$
\text { قسم الوقاية و المكافحة المتكاملة ـ كلية الزر اعة ـ جامعة مؤتةــ الكرك ـ الأردن }
$$

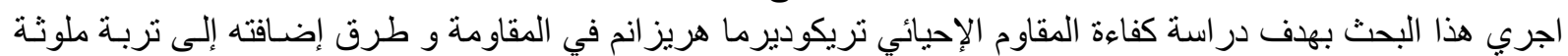

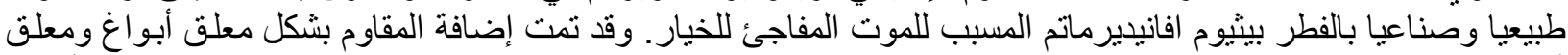

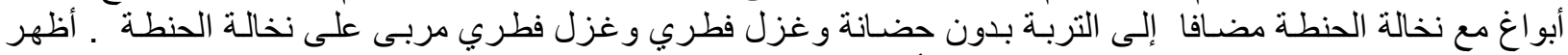

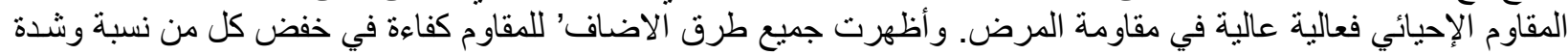

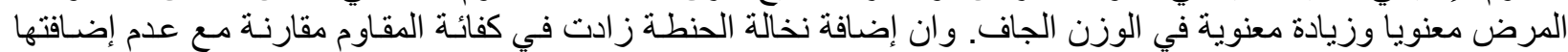

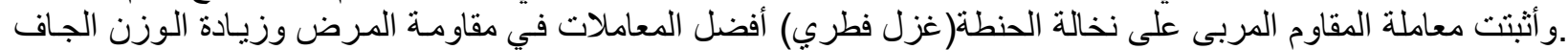

